\title{
Neonatal scleroderma
}

\author{
INSERM
}

\section{Source}

INSERM. (1999). Orphanet: an online rare disease and orphan drug data base. Neonatal scleroderma. ORPHA:398127

Neonatal scleroderma is a very rare, secondary, neonatal autoimmune disease characterized by neonatal-onset of erythematous skin lesions with a linear appearance that gradually become indurated and hyperpig mented and progressively present skin atrophy. Positive serum antibodies (in particular antinuclear antibodies and/or rheumatoid factor) may be associated. 